\title{
Production of Ethanol from Sugars and Lignocellulosic Biomass by Thermoanaerobacter J1 Isolated from a Hot Spring in Iceland
}

\author{
Jan Eric Jessen and Johann Orlygsson \\ Faculty of Natural Resource Sciences, University of Akureyri, Borgir, Nordurslod 2, 600 Akureyri, Iceland \\ Correspondence should be addressed to Johann Orlygsson, jorlygs@unak.is
}

Received 8 June 2012; Revised 16 August 2012; Accepted 4 September 2012

Academic Editor: Anuj K. Chandel

Copyright (๑) 2012 J. E. Jessen and J. Orlygsson. This is an open access article distributed under the Creative Commons Attribution License, which permits unrestricted use, distribution, and reproduction in any medium, provided the original work is properly cited.

\begin{abstract}
Thermophilic bacteria have gained increased attention as candidates for bioethanol production from lignocellulosic biomass. This study investigated ethanol production by Thermoanaerobacter strain J1 from hydrolysates made from lignocellulosic biomass in batch cultures. The effect of increased initial glucose concentration and the partial pressure of hydrogen on end product formation were examined. The strain showed a broad substrate spectrum, and high ethanol yields were observed on glucose $(1.70 \mathrm{~mol} / \mathrm{mol})$ and xylose $(1.25 \mathrm{~mol} / \mathrm{mol})$. Ethanol yields were, however, dramatically lowered by adding thiosulfate or by cocultivating strain J1 with a hydrogenotrophic methanogen with acetate becoming the major end product. Ethanol production from $4.5 \mathrm{~g} / \mathrm{L}$ of lignocellulosic biomass hydrolysates (grass, hemp stem, wheat straw, newspaper, and cellulose) pretreated with acid or alkali and the enzymes Celluclast and Novozymes 188 was investigated. The highest ethanol yields were obtained on cellulose $\left(7.5 \mathrm{mM} \cdot \mathrm{g}^{-1}\right)$ but the lowest on straw $\left(0.8 \mathrm{mM} \cdot \mathrm{g}^{-1}\right)$. Chemical pretreatment increased ethanol yields substantially from lignocellulosic biomass but not from cellulose. The largest increase was on straw hydrolysates where ethanol production increased from $0.8 \mathrm{mM} \cdot \mathrm{g}^{-1}$ to $3.3 \mathrm{mM} \cdot \mathrm{g}^{-1}$ using alkali-pretreated biomass. The highest ethanol yields on lignocellulosic hydrolysates were observed with hemp hydrolysates pretreated with acid, $4.2 \mathrm{mM} \cdot \mathrm{g}^{-1}$.
\end{abstract}

\section{Background}

More than $95 \%$ of the ethanol produced today is from simple biomass like mono- and disaccharides and starch [1]. The use of this type of biomass has been increasingly debated due to its impact on food and feed prices as well as for environmental reasons [2]. Therefore, complex (lignocellulosic) biomass has been put forward as a feasible alternative due to its abundance in nature and the large quantities generated as waste from agricultural activities $[2,3]$. Lignocellulosic biomass is primarily composed of cellulose, hemicellulose, and lignin. Cellulose and hemicellulose are the main substrates used for ethanol production, but lignin is composed of aromatic lignols that need to be separated and removed before enzymatic hydrolysis. Today, expensive pretreatments are the main reason for unsuccessful implementation of complex lignocellulosic biomasses as a starting material for ethanol production [2].
The best-known microorganisms used for ethanol production today are the yeast Saccharomyces cerevisiae and the bacterium Zymomonas mobilis. Both organisms have very high yields of ethanol $(>1.9 \mathrm{~mol}$ ethanol $/ \mathrm{mol}$ hexose) but very narrow substrate spectra and thus are not suitable for ethanol production from complex substrates. Therefore, the use of thermophilic bacteria with broad substrate range and high yields may be a better option for ethanol production from complex biomasses. It has been known for some time now that many thermophilic bacteria are highly efficient ethanol producers [4]. After the oil crisis in the 1980s, there was a peak in investigations on thermophilic ethanol-producing bacteria; bacteria within the genera of Thermoanaerobacterium, Thermoanaerobacter, and Clostridium have demonstrated good ethanol yields and fast growth rates [5-8]. There are several advantages in using these thermophilic bacteria: the increased temperature deters contamination from mesophilic bacteria and fungi, 
possible self-distillation of ethanol avoiding the generally low ethanol tolerance problem with those bacteria, and broad substrate spectrum $[9,10]$. Some of these strains produce more than $1.5 \mathrm{~mol}$ ethanol/mol hexose [11-16], whereas the theoretical maximum yield is $2.0 \mathrm{~mol}$ ethanol $/ \mathrm{mol}$ hexose degraded. The main reasons for low yields are the formation of other end products such as acetate, butyrate, and $\mathrm{CO}_{2}$ [11-16].

The present study focuses on a recently isolated thermophilic bacterium, strain J1, which is most closely related to species within the genus Thermoanaerobacter. Bacteria within this genus seem to be among the most efficient ethanol producers known and show very high yields from simple sugar fermentations $[12-14,16]$ as well as from complex lignocellulosic biomass [10, 13, 17-19]. These bacteria are Gram-variable rods with broad substrate spectrum (mostly sugars) and produces ethanol, acetate, lactate, hydrogen, and carbon dioxide during anaerobic fermentation [20, 21]. The physiological characteristics of Thermoanaerobacter strain $\mathrm{J1}$, isolated from Icelandic hot spring, were investigated in detail with the main aim of exploring the ethanol production capacity both from simple sugars as well as from various lignocellulosic biomass.

\section{Methods}

2.1. Medium. The composition and preparation of the medium used has been described earlier [12]. This medium, referred to as basal medium (BM) hereafter, contains yeast extract $(2 \mathrm{~g} / \mathrm{L})$ in addition to glucose or other carbon sources. All experiments were performed at $65^{\circ} \mathrm{C}$ at $\mathrm{pH} 7.0$ without agitation with the exception of the temperature and $\mathrm{pH}$ optimum experiments. The inoculum volume was $2 \%$ $(\mathrm{v} / \mathrm{v})$ in all experiments which were always performed in duplicates.

2.2. Isolation of Strain J1. The strain was isolated in BM with glucose $(20 \mathrm{mM})$ from a hot spring $\left(69^{\circ} \mathrm{C}, \mathrm{pH} 7.5\right)$ in Grensdalur in Southwest of Iceland. Samples were enriched on glucose, and positive samples (increase in growth and production of hydrogen) were reinoculated five times. From the final enrichment series, end point dilutions were performed by using BM containing agar $\left(30 \mathrm{~g} \cdot \mathrm{L}^{-1}\right)$. Colonies were picked from final positive dilution and reinoculated to liquid BM with glucose. Isolation of the hydrogenotrophic methane producing strain has been described elsewhere [22].

2.3. Optimum $p H$ and Temperature Growth Experiments. To determine the strain's growth characteristics at various $\mathrm{pHs}$ and temperatures, the strain was cultivated on glucose $(20 \mathrm{mM})$, and cell concentration was measured by increase in absorbance at $600 \mathrm{~nm}$ by a Perkin-Elmer Lambda $25 \mathrm{UV}$-Vis spectrophotometer. Maximum (specific) growth rate $\left(\mu_{\max }\right)$ for each experiment was derived from absorbance data. For $\mathrm{pH}$ optimum experiments, the initial $\mathrm{pH}$ was set to various levels in the range from 3.0 to 9.0 with increments of 1.0 $\mathrm{pH}$ unit. The experimental bottles were supplemented with acid $(\mathrm{HCl})$ and alkali $(\mathrm{NaOH})$ to set the $\mathrm{pH}$ accordingly.
To determine the optimum temperature for growth, the incubation temperature varied from $35^{\circ} \mathrm{C}$ to $80^{\circ} \mathrm{C}$. For the $\mathrm{pH}$ optimum experiments, the strain was cultivated at $65^{\circ} \mathrm{C}$, and for the temperature optimum experiments, the $\mathrm{pH}$ was 7.0. Optimal $\mathrm{pH}$ and temperature were used in all experiments performed. Experiments were done in $117.5 \mathrm{~mL}$ serum bottles with $50 \mathrm{~mL}$ liquid medium.

2.4. Phylogenetic Analysis. Full $16 \mathrm{~S}$ rRNA analysis of 1479nucleotide long sequence was done according to Orlygsson and Baldursson [23] and references therein. Sequences from $16 \mathrm{~S}$ rRNA analysis were compared to sequences in the NCBI database using the nucleotide-nucleotide BLAST (BLASTN) tool. The most similar sequences were aligned with the sequencing results in the programs BioEdit [24] and CLUSTAL_X [25]. Finally, the trees were displayed with the program TreeView. Caloramator viterbiensis was used as an outgroup.

\subsection{Effect of Initial Glucose Concentration on End Product} Formation. The effect of initial glucose concentration on strain J1, by varying the concentration from 5 to $200 \mathrm{mM}$, was tested. Control samples contained only yeast extract. Glucose, hydrogen, acetate, and ethanol concentrations were measured at the beginning and at the end of incubation time (7 days). Experiments were done in $117.5 \mathrm{~mL}$ serum bottles with $60 \mathrm{~mL}$ liquid medium, and the $\mathrm{pH}$ was measured at the end of incubation time.

2.6. Substrate Utilization Spectrum. The ability of strain J1 to utilize different substrates was tested using the BM medium supplemented with various carbon substrates (xylose, arabinose, glucose, mannose, galactose, fructose, rhamnose, maltose, cellobiose, sucrose, lactose, trehalose, raffinose, starch, cellulose, CMC, avicel, xylan (from oat spelt), glycerol, pyruvate, serine, and threonine). All substrates were added from filter-sterilized $(0.45 \mu \mathrm{m})$ substrates except for xylan, starch, CMC, cellulose, and avicel which were autoclaved with the medium. In all cases, the concentration of substrates was $20 \mathrm{mM}$ except for xylan, starch, CMC, cellulose, and avicel when $2 \mathrm{~g} \cdot \mathrm{L}^{-1}$ was used. Hydrogen, acetate, and ethanol concentrations were analysed after one week of incubation. Experiments were performed in $24.5 \mathrm{~mL}$ serum bottles with $10 \mathrm{~mL}$ liquid medium.

2.7. Pretreatment of Biomass and Hydrolysates Preparation. Hydrolysates (HLs) were made from different biomasses: Whatman no. 1 filter paper, newspaper, hemp stem (Cannabis sativa), barley straw (Hordeum vulgare), and grass (Phleum pratense). Hydrolysates were prepared according to Sveinsdottir et al. [12], and the final concentration of each biomass type was $22.5 \mathrm{~g} \cdot \mathrm{L}^{-1}$. Biomass was pretreated chemically by using $0.50 \%(\mathrm{v} / \mathrm{v})$ of acid $\left(\mathrm{H}_{2} \mathrm{SO}_{4}\right)$ or alkali $(\mathrm{NaOH})$ (control was without chemical pretreatment) before heating $\left(121^{\circ} \mathrm{C}, 60 \mathrm{~min}\right)$. Two commercial enzyme solutions, Celluclast (Novozyme, $750 \mathrm{U} \cdot \mathrm{g}^{-1}$ ) and Novozyme 188 (Sigma C6105, $200 \mathrm{U} \cdot \mathrm{g}^{-1}$ ), were added to each bottle after chemical pretreatment; the bottles were cooled down to 


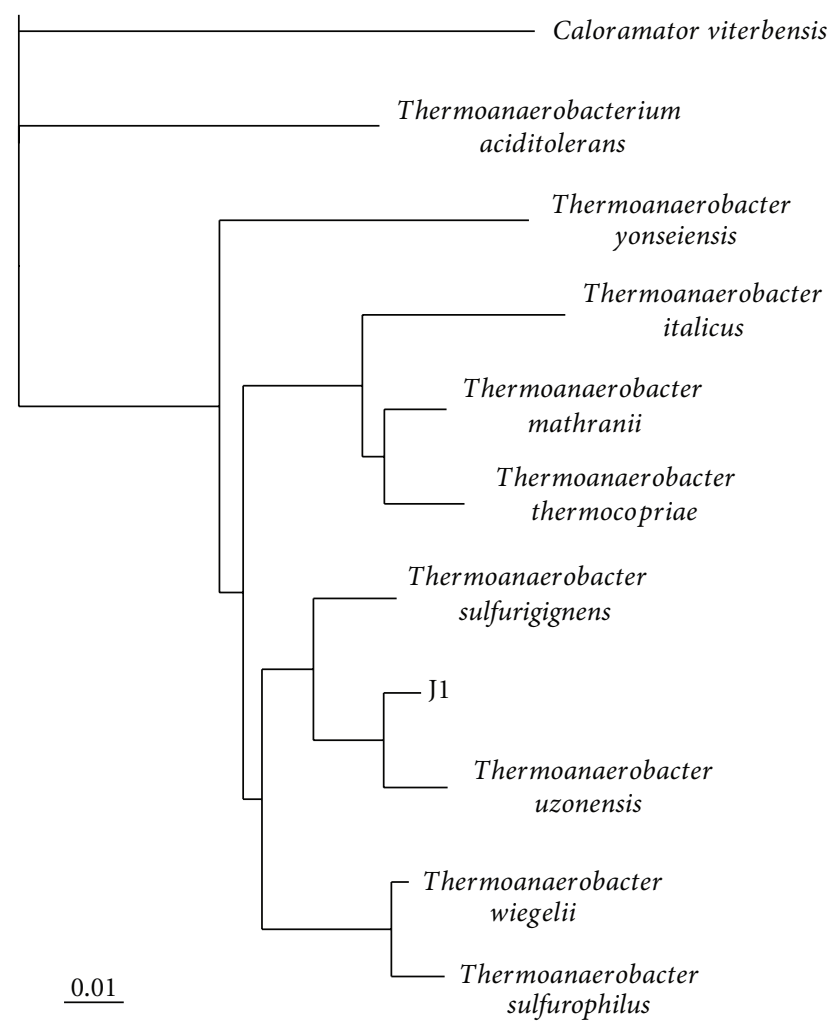

Figure 1: Phylogeny of strain J1 based on partial 16S rRNA sequence analysis. The phylogenetic tree was generated by using distance matrix and neighbor-joining algorithms. Caloramator viterbensis was selected as outgroup. The bar indicates 0.01 substitutions per nucleotide position.

room temperature and the $\mathrm{pH}$ adjusted to 5.0 before enzymes were added. The hydrolysates were incubated in water bath at $45^{\circ} \mathrm{C}$ for $68 \mathrm{~h}$. After the enzyme treatment, the $\mathrm{pH}$ was adjusted with $\mathrm{NaOH}$ or $\mathrm{HCl}$ to $\mathrm{pH} 7.0$ which is the $\mathrm{pH}$ optimum of the strain. The hydrolysates were then filtered (Whatman-WeiBrand; $0.45 \mu \mathrm{m}$ ) into sterile bottles.

2.8. Fermentation during External Electron-Scavenging Systems. In one set of experiments, strain J1 was incubated on glucose $(20 \mathrm{mM})$ in the presence of sodium thiosulfate $(40 \mathrm{mM})$ and in coculture with a hydrogenotrophic methanogen. The methanogen was precultivated in $\mathrm{BM}$ medium with a gas phase consisting of $80 \%$ of $\mathrm{H}_{2}$ and $20 \%$ of $\mathrm{CO}_{2}$ for one week. Then the experimental culture bottles were flushed with nitrogen prior to the addition of glucose $(20 \mathrm{mM})$ and strain $\mathrm{J} 1$. The coculture was incubated at $65^{\circ} \mathrm{C}$ for one week.

2.9. Fermentation of Hydrolysates. Fermentation of carbohydrates present in the hydrolysates after chemical and enzymatic pretreatment was performed in $24.5 \mathrm{~mL}$ serum bottles. The BM medium and inoculum $(8.0 \mathrm{~mL})$ were supplemented with different hydrolysates $(2.0 \mathrm{~mL}$, total liquid volume of $10 \mathrm{~mL}$ ) giving a final hydrolysate concentration of $4.5 \mathrm{~g} \cdot \mathrm{L}^{-1}$. Control samples did not contain hydrolysate; the only carbon source was yeast extract.

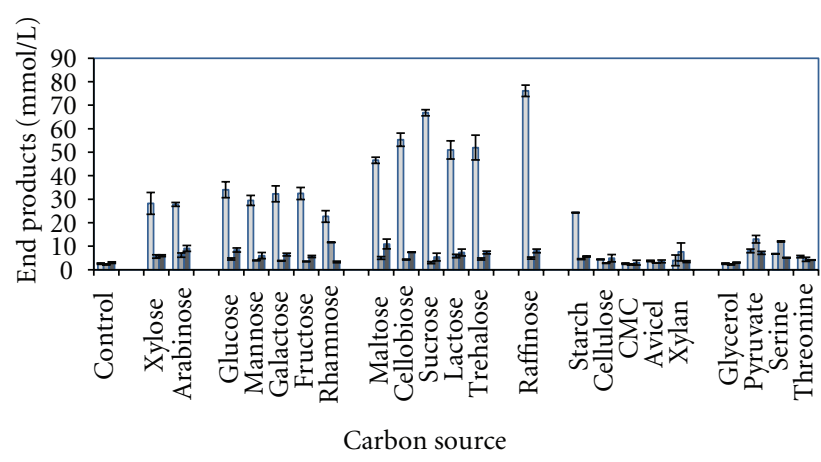

FIGURE 2: End product formation from various substrates by strain J1. Data represents average of two replicate experiments. Standard deviation are shown as error bars. From left to right; ethanol, acetate and hydrogen.

2.10. Analytical Methods. Hydrogen, ethanol, and volatile fatty acids were measured by gas chromatography as previously described [23]. Glucose was determined by slight modification of the method from Laurentin and Edwards [26]; supernatant broth $(400 \mu \mathrm{L})$ was mixed with $2 \mathrm{~mL}$ of anthrone solution $(0.2 \%(\mathrm{w} / \mathrm{v})$ of anthrone in $72 \%$ $(\mathrm{v} / \mathrm{v})$ of sulphuric acid). The sample was boiled for 11 minutes and then cooled down on ice. Absorbance was then measured at $600 \mathrm{~nm}$ by using Perkin-Elmer Lambda 25 UVVis spectrophotometer.

\section{Results and Discussion}

3.1. Phylogeny. Figure 1 shows that strain J1 belongs to the genus Thermoanaerobacter with its closest neighbours being T. uzonensis (97.7\% homology) and T. sulfurigenes (95.5\%). The genus Thermoanaerobacter falls into clusters $\mathrm{V}$ in the phylogenetic interrelationship of Clostridium according to Collins and coworkers [27]. All species within the genus are obligate anaerobes and ferment various carbohydrates to ethanol, acetate, lactate, hydrogen, and carbon dioxide [20], while some species can degrade amino acids [28]. Most strains can reduce thiosulfate to hydrogen sulphide [20, 28]. Today, the genus consists of 18 species according to the Euzeby list of prokaryotes.

3.2. Optimum Growth Conditions. The strain was able to grow between $55.0^{\circ} \mathrm{C}$ and $75.0^{\circ} \mathrm{C}$ with optimal temperature being $65.0^{\circ} \mathrm{C}\left(\mu_{\max } ; 0.23 \mathrm{~h}\right)$. The $\mathrm{pH}$ optimum was $7.0\left(\mu_{\max }\right.$; $0.19 \mathrm{~h})$. No growth was observed below $\mathrm{pH} 4.0$ and above $\mathrm{pH} 9.0$.

3.3. End Product Production from Sugars and Other Substrates. One of the main reasons for increased interest in using thermophilic bacteria for second-generation ethanol production is because of their broad substrate spectrum. Therefore, it was decided to cultivate the strain on the most common sugars present in lignocellulosic biomass as well as pyruvate, glycerol, serine, and threonine (Figure 2). Clearly, the strain is a very powerful ethanol producer; it produces $1.70 \mathrm{~mol}$ ethanol $/ \mathrm{mol}$ glucose and $1.25 \mathrm{~mol}$ ethanol $/ \mathrm{mol}$ 
xylose (control values subtracted) or 85.0 and $75.0 \%$ of theoretical yields, respectively. The following stoichiometry from glucose and xylose was observed:

$$
\begin{aligned}
1.0 \text { Glucose } \longrightarrow & 1.70 \mathrm{EtOH}+0.15 \text { Acetate } \\
+ & 0.30 \mathrm{H}_{2}+1.85 \mathrm{CO}_{2} \\
1.0 \text { Xylose } \longrightarrow & 1.25 \mathrm{EtOH}+0.20 \text { Acetate } \\
+ & 0.20 \mathrm{H}_{2}+1.45 \mathrm{CO}_{2}
\end{aligned}
$$

Lactate was not analysed in the present paper, but high carbon recoveries from analysed end products from glucose and xylose ( 92.5 and $87.4 \%$, resp.) indicate that if it was produced, its significance is very little. The substrate spectrum of the strain shows a broad capacity in degrading pentoses (xylose, arabinose), hexoses (glucose, mannose, galactose, fructose, and rhamnose), disaccharides (maltose, cellobiose, lactose, trehalose, and sucrose) the trisaccharide raffinose, and starch, pyruvate, and serine. In all the cases, the major end product is ethanol except for serine and pyruvate in which acetate is the primary end product. The highest ethanol concentrations were produced from the trisaccharide raffinose $(75.2 \mathrm{mM})$. As earlier mentioned, the strain is most closely related to T. uzonensis (strain JW/IW010) which also produces ethanol and acetate as the only volatile end products, but the ratio between ethanol and acetate is 1.35 in that strain [28]. However, T. uzonensis has a more narrow sugar degradation spectrum as compared to strain $\mathrm{J} 1$; it cannot degrade arabinose and rhamnose. Other well-known ethanol producers within the genus are T. ethanolicus, $T$. thermohydrosulfuricus, and T. finnii with yields between 1.5 and $1.9 \mathrm{~mol}$ ethanol/mol glucose $[11,13,14,29]$.

During growth on serine and pyruvate, the carbon flow was shifted away from ethanol to acetate and hydrogen. This can be explained by the oxidation state of these substrates as compared to sugars; the oxidation state of the carbon in glucose is zero, and during its oxidation to pyruvate, the electrons are transferred to $\mathrm{NAD}^{+}$leading to the formation of NADH. Reoxidation of NADH to $\mathrm{NAD}^{+}$by the strain occurs most likely through acetaldehyde dehydrogenase and alcohol dehydrogenase rendering ethanol as the main product. However, both pyruvate and serine are more oxidized substrates as compared to sugars (glucose), and there is no need to reoxidize NADH. Instead, the strain deaminates serine directly to pyruvate which is decarboxylated to acetyl phosphate (by phosphotransacetylase) and further to acetate (by acetate kinase) resulting in ATP formation. However, since hydrogen production is less as compared to acetate, it is likely that the strain is also producing formate (not analyzed) instead of hydrogen from these substrates.

\subsection{Effect of Initial Glucose Loadings on Ethanol Production.} High initial substrate concentrations may inhibit substrate utilization and/or decrease end product yields $[5,10,30]$. In closed systems, such as batch cultures, the limited buffer capacity of the medium may be overloaded by the accumulation of organic acids resulting in a $\mathrm{pH}$ drop and the inhibition of substrate fermentation utilization

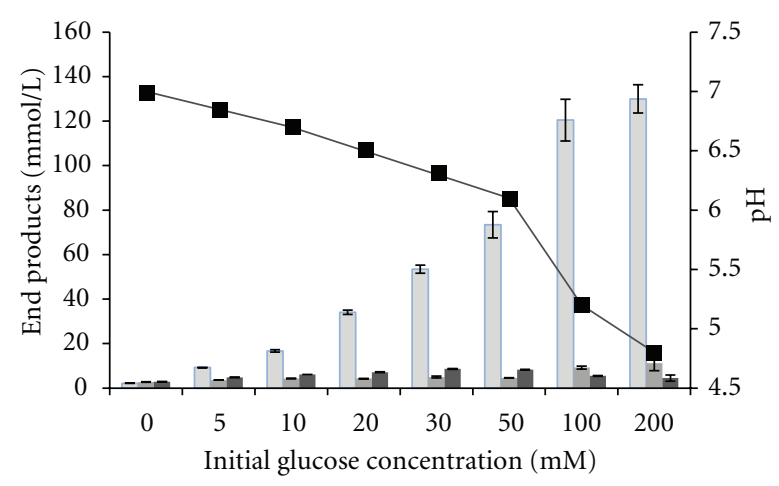

FIGURE 3: End product formation from different initial glucose concentrations. Also shown are percent of glucose degraded. Values represent means of two replicates and standard deviation are shown as error bars. Columns from left to right; ethanol, acetate, hydrogen. $\mathrm{pH}$ measered after fermentation ( $\mathbf{\square})$.

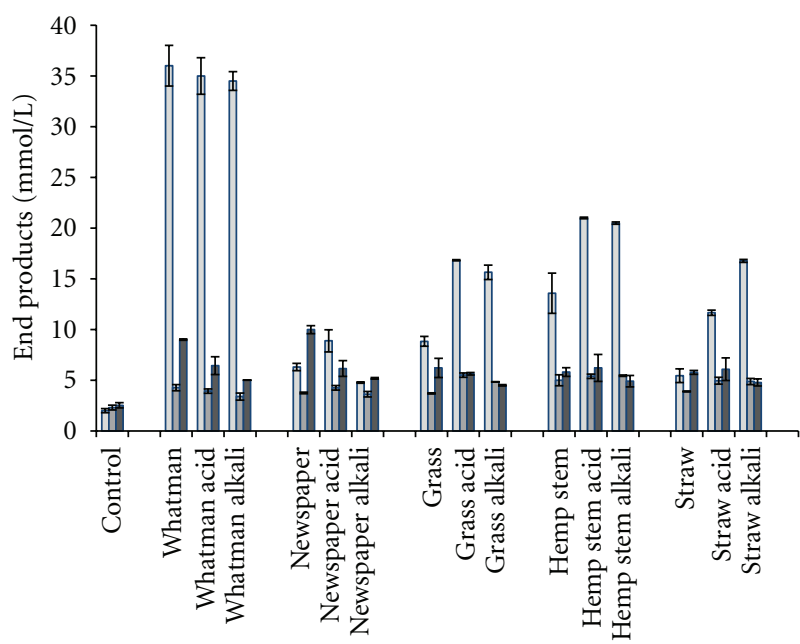

Figure 4: Production of end products from hydrolysates $\left(4.5 \mathrm{~g} \cdot \mathrm{L}^{-1}\right)$ from different biomasses. Values represent mean of two replicates ( \pm standard deviation). From left to right: ethanol, acetate, and hydrogen.

[30]. To investigate the influence of initial substrate concentration on end product formation, changes in $\mathrm{pH}$, and substrate degradation, strain $\mathrm{J} 1$ was cultivated with different concentration of glucose (0 to $200 \mathrm{mM}$ ). The strain completely degraded glucose in all experiments, except for the highest $(200 \mathrm{mM})$ initial glucose loadings, and ethanol yields were between 1.2 and $1.7 \mathrm{~mol}$ ethanol $/ \mathrm{mol}$ glucose (Figure 3). Acetate formation increased from $2.7 \mathrm{mM}$ in control bottles (without glucose) to $9.5 \mathrm{mM}$ at $100 \mathrm{mM}$ glucose concentrations which was directly linked to a decrease from pH 7.0 (control) to 5.2 (100 mM glucose). At $200 \mathrm{mM}$ glucose concentrations, acetate was only slightly higher as compared to $100 \mathrm{mM}$ glucose concentrations, the $\mathrm{pH}$ dropped from 5.2 to 4.8 , and only $110 \mathrm{mM}$ of glucose was degraded. Thus, the limit of glucose seems to be $\mathrm{pH}$ related, because of the formation of acetate, rather than 
TABLE 1: Utilization of glucose by strain J1 in the presence of thiosulfate or a hydrogenotrophic methanogen. Data represents average of two replicate experiments \pm standard deviation.

\begin{tabular}{lcccr}
\hline & \multicolumn{3}{c}{ Concentration $\left(\mathrm{mmol} \cdot \mathrm{L}^{-1}\right)$} \\
& Ethanol & Acetate & Hydrogen & Methane \\
\hline Control & $3.0 \pm 0.1$ & $2.9 \pm 0.1$ & $2.0 \pm 0.1$ & $0.0 \pm 0.0$ \\
Control $+\mathrm{S}_{2} \mathrm{O}_{3}$ & $1.1 \pm 0.1$ & $5.2 \pm 0.2$ & $0.3 \pm 0.0$ & $0.0 \pm 0.0$ \\
Control + methanogen & $0.9 \pm 0.5$ & $4.9 \pm 0.4$ & $0.0 \pm 0.0$ & $2.4 \pm 0.0$ \\
Glucose & $29.0 \pm 1.5$ & $4.2 \pm 0.3$ & $7.2 \pm 0.5$ & $0.0 \pm 0.0$ \\
Glucose $+\mathrm{S}_{2} \mathrm{O}_{3}$ & $20.0 \pm 0.3$ & $15.5 \pm 2.1$ & $0.3 \pm 0.1$ & $0.0 \pm 0.0$ \\
Glucose + methanogen & $4.1 \pm 0.2$ & $29.5 \pm 1.2$ & $0.5 \pm 0.0$ & $7.4 \pm 1.2$ \\
\hline
\end{tabular}

substrate inhibition. The strain seems to be more tolerant for initial substrate concentrations as compared to many other thermophilic bacteria where often a concentration between 20 and $30 \mathrm{mM}$ is too high for a complete degradation $[7,8]$. In those cases, however, more acetate was produced as compared to ethanol and may be crucial for lowering the $\mathrm{pH}$ at lower substrate concentrations.

3.5. Effect of Hydrogen-Scavenging Systems on End Product Formation. It is well known that Thermoanaerobacter species are highly flexible concerning end product formation depending on the culture conditions. Fardeau et al. [31] showed a dramatic shift in end product formation by Thermoanaerobacter finnii when grown on glucose in the presence and absence of thiosulfate. In that case, both ethanol and lactate decreased during thiosulfate reduction to hydrogen sulphide, whereas the acetate concentration increased. The influence of using biological hydrogen-scavenging systems has also been investigated throughout Thermoanaerobacter brockii during amino acid degradation [27]. Both thiosulfate and the presence of a hydrogen-scavenging methanogen were crucial for the oxidative deamination of the branched chain amino acids by this strain. However, degradation of a substrate that is thermodynamically easier to degrade, for example, the amino acid serine, was completely degraded in the presence and absence of thiosulfate and Methanobacterium sp. although a shift occurred between ethanol and acetate formation [27]. To investigate the influence of low partial pressure $\left(p \mathrm{H}_{2}\right)$ on end product formation, strain J1 was cultivated in the presence of thiosulfate and in coculture with a hydrogenotrophic methanogen. As observed earlier, strain $\mathrm{J} 1$ produced ethanol as the main end product during glucose fermentation only (Table 1). The addition of thiosulfate to glucose fermentations resulted in a shift towards acetate from ethanol where the ratio between ethanol and acetate changed from 6.90 to 1.29. Cocultivating strain J1 with a hydrogenotrophic methanogen led even to more dramatic shift towards acetate (and methane), and the ratio of ethanol and acetate was 0.14 . This difference in end product formation by using thiosulfate or a hydrogenotrophic methanogen is surprisingly big considering that the concentration of hydrogen is very low at the end of experimental time $(0.3$ to $\left.0.5 \mathrm{mmol} \cdot \mathrm{L}^{-1}\right)$ in both cases. This difference could be caused by more rapid uptake of hydrogen in the coculture experiment, but end products were only analysed at the end of the experimental time.

3.6. Fermentation of Hydrolysates from Lignocellulosic Biomass. The strain is producing maximally $33.9 \mathrm{mM}(1.56 \mathrm{~g} / \mathrm{L})$ of ethanol from $4.5 \mathrm{~g} / \mathrm{L}$ of hydrolysates made from cellulose (Figure 4). The yields on cellulose pretreated only with enzymes and heat are $7.5 \mathrm{mM} \cdot \mathrm{g}^{-1}$ dry weight $(\mathrm{dw})$ which is considered lower as compared to glucose degradation alone ( $1.70 \mathrm{~mol}$ ethanol$/ \mathrm{mol}$ glucose; $9.4 \mathrm{mM} \cdot \mathrm{g}^{-1}$ glucose). No glucose was analysed in the cellulose hydrolysate after fermentation. Thus, the lower ethanol yields on cellulose as compared to glucose indicate that the cellulose was not completely degraded during enzymatic hydrolysis. Chemical pretreatment of cellulose by the addition of acid or alkali did not increase the end product formation yields on cellulose. The highest ethanol yields on the more complex biomass types (without chemical pretreatment) were observed on hemp $\left(11.6 \mathrm{mM} ; 2.6 \mathrm{mM} \cdot \mathrm{g}^{-1} \mathrm{dw}\right)$ but lowest on straw $\left(3.5 \mathrm{mM} ; 0.8 \mathrm{mM} \cdot \mathrm{g}^{-1} \mathrm{dw}\right)$. Chemical pretreatment by adding either acid or alkali increased yields substantially on most of the lignocellulosic biomasses tested. The increase was most profound on hydrolysates from straw pretreated with alkali where ethanol production was increased from 3.5 to $14.8 \mathrm{mM}$ (controls subtracted). The highest ethanol yields were however observed on hemp, $4.3 \mathrm{mM} \cdot \mathrm{g}^{-1} \mathrm{dw}(19.0 \mathrm{mM})$. The highest ethanol yields by Thermoanaerobacter species have been reported by continuous cultures of Thermoanaerobacter strain BG1L1 on wheat straw [17] and corn stover [18], or $8.5-9.2 \mathrm{mM} \cdot \mathrm{g}^{-1}$ sugar consumed. Thermoanaerobacter ethanolicus has been reported to produce 4.5 and $4.8 \mathrm{mM}$ ethanol. $\mathrm{g}^{-1}$ hexose equivalent degraded from wood hydrolysate and beet molasses, respectively $[13,32]$. Thermoanaerobacter mathranii, isolated from the same geographical area in Iceland [33] as strain $\mathrm{J1}$ produced $5.3 \mathrm{mM} \cdot \mathrm{g}^{-1}$ sugar from wheat straw hydrolysate [34]. Recently, a new Thermoanaerobacter strain, $\mathrm{AK}_{5}$ closely related to $T$. thermohydrosulfuricus and T. ethanolicus, was isolated from a hot spring in Iceland and has similar yields on cellulose $\left(7.7 \mathrm{mM} \cdot \mathrm{g}^{-1}\right)$, hemp $\left(3.1 \mathrm{mM} \cdot \mathrm{g}^{-1}\right)$, and grass $\left(4.1 \mathrm{mM} \cdot \mathrm{g}^{-1}\right)$ hydrolysates [22]. 


\section{Conclusion}

Ethanol production was studied by Thermoanaerobacter J1 isolated from hot spring in Iceland. The main aim of the study was to investigate the importance of various factors on ethanol production from both sugars and complex lignocellulosic biomass. The strain produces $1.70 \mathrm{~mol}$ ethanol $/ \mathrm{mol}$ glucose and $1.25 \mathrm{~mol}$ ethanol $/ \mathrm{mol}$ xylose and shows a broad substrate spectrum, degrading various sugars and starch but not cellulosic substrates. High ethanol yields were observed at initial glucose concentrations up to $100 \mathrm{mM}$. During growth under hydrogen removal, a shift from ethanol to acetate formation occurs. The strain produces up to $7.5 \mathrm{mM}$ ethanol $\cdot \mathrm{g}^{-1}$ cellulose and $4.2 \mathrm{mM} \cdot \mathrm{g}^{-1}$ hemp hydrolysate.

\section{Authors' Contribution}

J. E. Jessen carried out all experimental procedures. J. Orlygsson planned the experimental procedure and drafted the paper. Both authors read and approved the final paper.

\section{Conflict of Interests}

The authors declare that there is no conflict of interests.

\section{Acknowledgments}

This work was sponsored by RANNÍS, Technology Development Fund, projects 081303408 (BioEthanol) and RAN091016-2376 (BioFuel), and the Research Fund of the University of Akureyri. Special thanks are due to Margret Audur Sigurbjornsdottir for aligning the 16S rRNA sequences and building the phylogenetic tree and to Sean M. Scully for proofreading the paper.

\section{References}

[1] Renewable Fuels Association, “Choose ethanol," 2011, http:// chooseethanol.com/what-is-ethanol/entry/ethanol-at-a-glance/.

[2] Ó. J. Sánchez and C. A. Cardona, "Trends in biotechnological production of fuel ethanol from different feedstocks," Bioresource Technology, vol. 99, no. 13, pp. 5270-5295, 2008.

[3] J. Zaldivar, J. Nielsen, and L. Olsson, "Fuel ethanol production from lignocellulose: a challenge for metabolic engineering and process integration," Applied Microbiology and Biotechnology, vol. 56, no. 1-2, pp. 17-34, 2001.

[4] J. Wiegel, "Formation of ethanol by bacteria. A pledge for the use of extreme thermophilic anaerobic bacteria in industrial ethanol fermentation processes," Experientia, vol. 36, no. 12, pp. 1434-1446, 1980.

[5] L. S. Lacis and H. G. Lawford, "Ethanol production from xylose by Thermoanaerobacter ethanolicus in batch and continuous culture," Archives of Microbiology, vol. 150, no. 1, pp. 48-55, 1988.

[6] R. Lamed and J. G. Zeikus, "Ethanol production by thermophilic bacteria: relationship between fermentation product yields of and catabolic enzyme activities in Clostridium thermocellum and Thermoanaerobium brockii," Journal of Bacteriology, vol. 144, no. 2, pp. 569-578, 1980.
[7] A. R. Almarsdottir, M. A. Sigurbjornsdottir, and J. Orlygsson, "Effect of various factors on ethanol yields from ligncellulosic biomass by Thermoanaerobacterium AK17," Biotechnology and Bioengineering, vol. 109, no. 3, pp. 686-694, 2012.

[8] M. A. Sigurbjornsdottir and J. Orlygsson, "Combined hydrogen and ethanol production from sugars and lignocellulosic biomass by Thermoanaerobacterium AK54," Applied Energy, vol. 97, pp. 785-791, 2012.

[9] M. P. Taylor, K. L. Eley, S. Martin, M. I. Tuffin, S. G. Burton, and D. A. Cowan, "Thermophilic ethanologenesis: future prospects for second-generation bioethanol production," Trends in Biotechnology, vol. 27, no. 7, pp. 398-405, 2009.

[10] P. Sommer, T. Georgieva, and B. K. Ahring, "Potential for using thermophilic anaerobic bacteria for bioethanol production from hemicellulose," Biochemical Society Transactions, vol. 32, no. 2, pp. 283-289, 2004.

[11] J. Wiegel and L. G. Ljungdahl, "Thermoanaerobacter ethanolicus gen. nov., spec. nov., a new, extreme thermophilic, anaerobic bacterium," Archives of Microbiology, vol. 128, no. 4, pp. 343-348, 1981.

[12] M. Sveinsdottir, S. R. B. Baldursson, and J. Orlygsson, "Ethanol production from monosugars and lignocellulosic biomass by thermophilic bacteria isolated from Icelandic hot springs," Icelandic Agricultural Sciences, vol. 22, pp. 45-58, 2009.

[13] A. Avci and S. Dönmez, "Effect of zinc on ethanol production by two Thermoanaerobacter strains," Process Biochemistry, vol. 41, no. 4, pp. 984-989, 2006.

[14] L. H. Carreira, J. Wiegel, and L. G. Ljungdahl, "Production of ethanol from biopolymers by anaerobic, thermophilic, and extreme thermophilic bacteria: I. Regulation of carbohydrate utilization in mutants of Thermoanaerobacter ethanolicus," Biotechnology Bioengineering Symposium, vol. 13, no. 13, pp. 183-191, 1983.

[15] P. E. P. Koskinen, S. R. Beck, J. Örlygsson, and J. A. Puhakka, "Ethanol and hydrogen production by two thermophilic, anaerobic bacteria isolated from Icelandic geothermal areas," Biotechnology and Bioengineering, vol. 101, no. 4, pp. 679-690, 2008.

[16] R. W. Lovitt, G. J. Shen, and J. G. Zeikus, "Ethanol production by thermophilic bacteria: biochemical basis for ethanol and hydrogen tolerance in Clostridium Thermohydrosulfuricum," Journal of Bacteriology, vol. 170, no. 6, pp. 2809-2815, 1988.

[17] T. I. Georgieva, M. J. Mikkelsen, and B. K. Ahring, "Ethanol production from wet-exploded wheat straw hydrolysate by thermophilic anaerobic bacterium Thermoanaerobacter BG1L1 in a continuous immobilized reactor," Applied Biochemistry and Biotechnology, vol. 145, no. 1-3, pp. 99-110, 2008.

[18] T. I. Georgieva and B. K. Ahring, "Evaluation of continuous ethanol fermentation of dilute-acid corn stover hydrolysate using thermophilic anaerobic bacterium Thermoanaerobacter BG1L1," Applied Microbiology and Biotechnology, vol. 77, no. 1, pp. 61-68, 2007.

[19] K. S. Rani, M. V. Swamy, and G. Seenayya, "Production of ethanol from various pure and natural cellulosic biomass by Clostridium Thermocellum strains SS21 and SS22," Process Biochemistry, vol. 33, no. 4, pp. 435-440, 1998.

[20] Y. E. Lee, M. K. Jain, C. Lee et al., "Taxonomic distinction of saccharolytic thermophilic anaerobes: description of Thermoanaerobacterium xylanolyticum gen. nov., sp. nov., and Thermoanaerobacterium saccharolyticum gen. nov., sp. nov., 
reclassification of Thermoanaerobium brockii, Clostridium thermosulfurogenes, and Clostridium thermohydrosulfuricum E100-69 as Thermoanaerobacter brockii comb. nov., Thermoanaerobacter thermosulfurigenes comb. nov., and Thermoanaerobacter thermohydrosulfuricus comb. nov., respectively, and transfer of Clostridium Thermohydrosulfuricum 39E to Thermoanaerobacter ethanolicus," International Journal of Systematic Bacteriology, vol. 43, no. 1, pp. 41-51, 1993.

[21] M. L. Fardeau, M. B. Salinas, S. L'Haridon et al., "Isolation from oil resorvoirs of novel thermophilic anaerobes phylogenetically related to Thermoanaerobacter subterraneus: reassignment of $T$. subterraneus, Thermoanaerobacter yonseiensis, Thermoanaerobacter tengcongensis and Carboxydibrachium pacificum to Caldanaerobacter subterraneus gen. nov., sp. nov., comb. nov. as four novel subspecies," International Journal of Systematic and Evolutionary Microbiology, vol. 54, no. 2, pp. 467-474, 2004.

[22] H. Brynjarsdottir, B. Wawiernia, and J. Orlygsson, "Ethanol production from sugars and complex biomass by Thermoanaerobacter AK5: the effect of electron scavenging systems on end product formation," Energy \& Fuels, vol. 26, no. 7, pp. 4568-4574, 2012.

[23] J. Orlygsson and S. R. B. Baldursson, "Phylogenetic and physiological studies of four hydrogen-producing thermoanaerobes from Icelandic geothermal areas," Icelandic Agricultural Sciences, vol. 93, pp. 93-106, 2007.

[24] T. A. Hall, "BioEdit: a user-friendly biological sequence alignment editor and analysis program for Windows 95/98/NT," Nucleic Acids Symposium Series, vol. 41, pp. 95-98, 1999.

[25] J. D. Thompson, T. J. Gibson, F. Plewniak, F. Jeanmougin, and D. G. Higgins, "The CLUSTAL X windows interface: flexible strategies for multiple sequence alignment aided by quality analysis tools," Nucleic Acids Research, vol. 25, no. 24, pp. 4876-4882, 1997.

[26] A. Laurentin and C. A. Edwards, "A microtiter modification of the anthrone-sulfuric acid colorimetric assay for glucosebased carbohydrates," Analytical Biochemistry, vol. 315, no. 1, pp. 143-145, 2003.

[27] M. D. Collins, P. A. Lawson, A. Willems et al., "The phylogeny of the genus Clostridium: proposal of five new genera and eleven new species combinations," International Journal of Systematic Bacteriology, vol. 44, no. 4, pp. 812-826, 1994.

[28] M. L. Fardeau, B. K. C. Patel, M. Magot, and B. Ollivier, "Utilization of serine, leucine, isoleucine, and valine by Thermoanaerobacter brockii in the presence of thiosulfate or Methanobacterium sp. as electron accepters," Anaerobe, vol. 3, no. 6, pp. 405-410, 1997.

[29] I. D. Wagner, W. Zhao, C. L. Zhang, C. S. Romanek, M. Rohde, and J. Wiegel, "Thermoanaerobacter uzonensis sp. nov., an anaerobic thermophilic bacterium isolated from a hot spring within the Uzon Caldera, Kamchatka, Far East Russia," International Journal of Systematic and Evolutionary Microbiology, vol. 58, no. 11, pp. 2565-2573, 2008.

[30] S. Van Ginkel, S. Sung, and J. J. Lay, "Biohydrogen production as a function of $\mathrm{pH}$ and substrate concentration," Environmental Science and Technology, vol. 35, no. 24, pp. 4726-4730, 2001.

[31] M. L. Fardeau, C. Faudon, J. L. Cayol, M. Magot, B. K. C. Patel, and B. Ollivier, "Effect of thiosulphate as electron acceptor on glucose and xylose oxidation by Thermoanaerobacter finnii and a Thermoanaerobacter sp. isolated from oil field water," Research in Microbiology, vol. 147, no. 3, pp. 159-165, 1996.
[32] J. Wiegel, L. H. Carreira, C. P. Mothershed, and J. Puls, "Production of ethanol from biopolymers by anaerobic, thermophilic, and extreme thermophilic bacteria. II. Thermoanaerobacter ethanolicus JW200 and its mutants in batch cultures and resting cell experiments," Biotechnology Bioengineering Symposium, vol. 13, no. 13, pp. 193-205, 1983.

[33] L. Larsen, P. Nielsen, and B. K. Ahring, “Thermoanaerobacter mathranii sp. nov., an ethanol-producing, extremely thermophilic anaerobic bacterium from a hot spring in Iceland," Archives of Microbiology, vol. 168, no. 2, pp. 114-119, 1997.

[34] B. K. Ahring, D. Licht, A. S. Schmidt, P. Sommer, and A. B. Thomsen, "Production of ethanol from wet oxidised wheat straw by Thermoanaerobacter mathranii," Bioresource Technology, vol. 68, no. 1, pp. 3-9, 1999. 

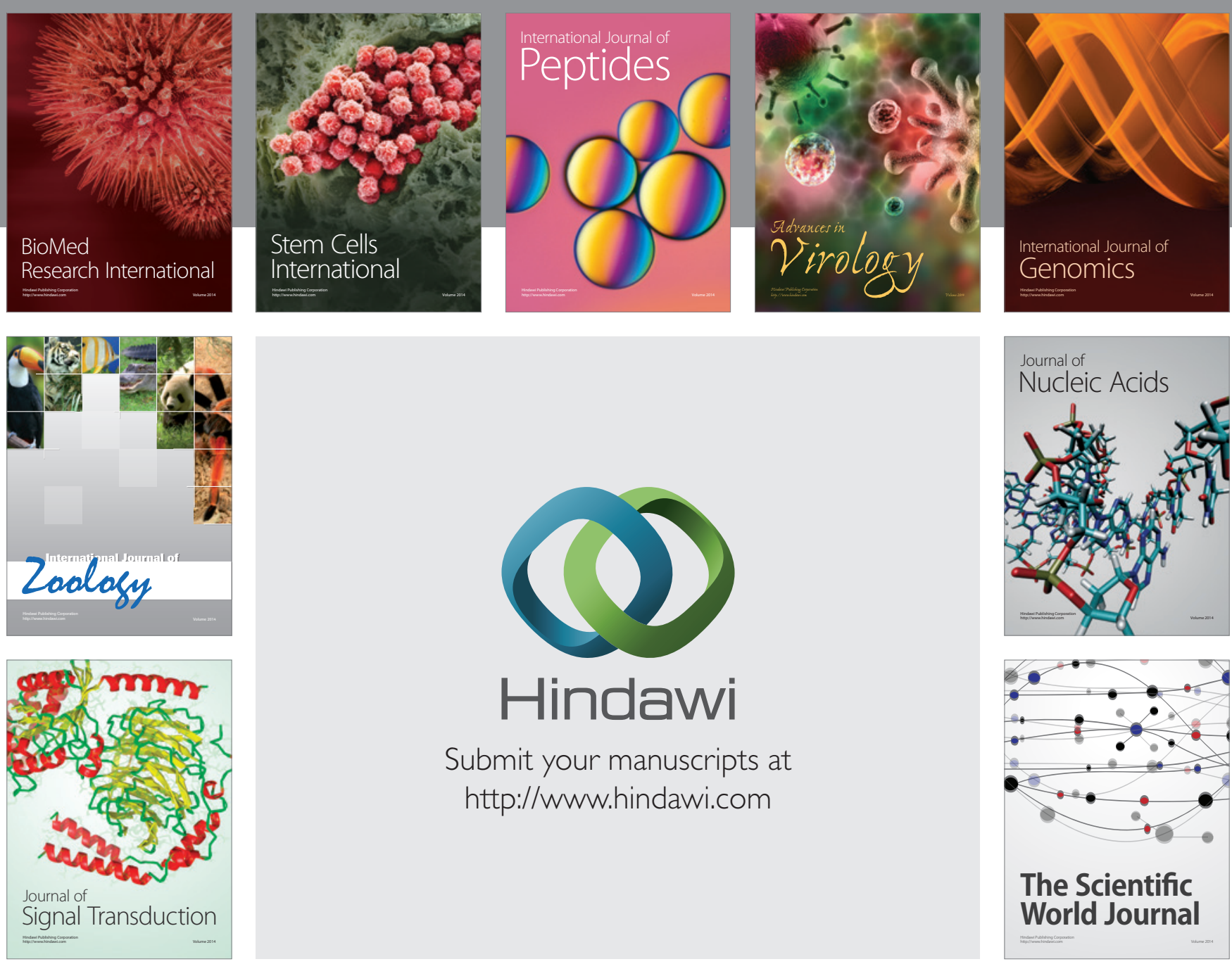

Submit your manuscripts at

http://www.hindawi.com
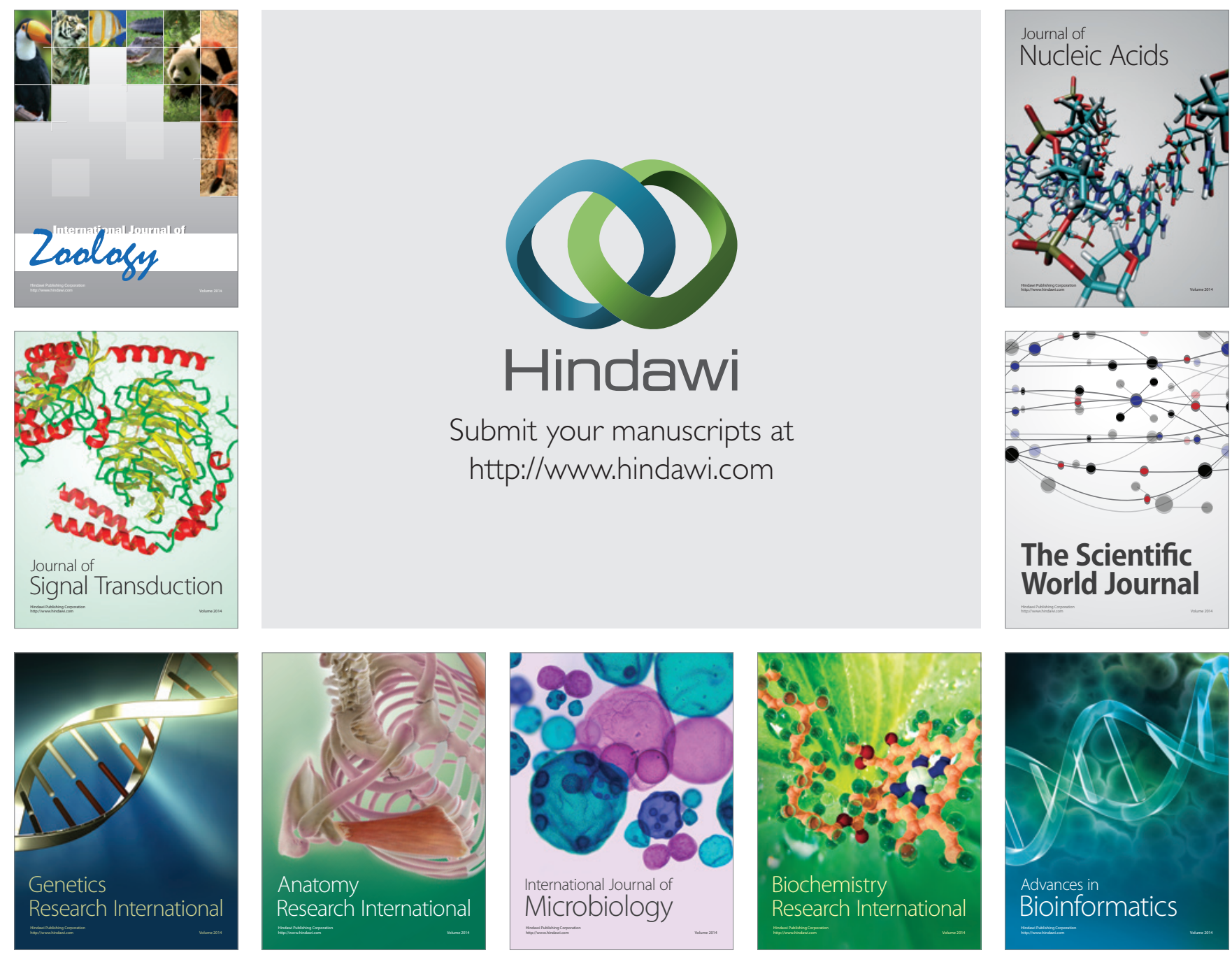

The Scientific World Journal
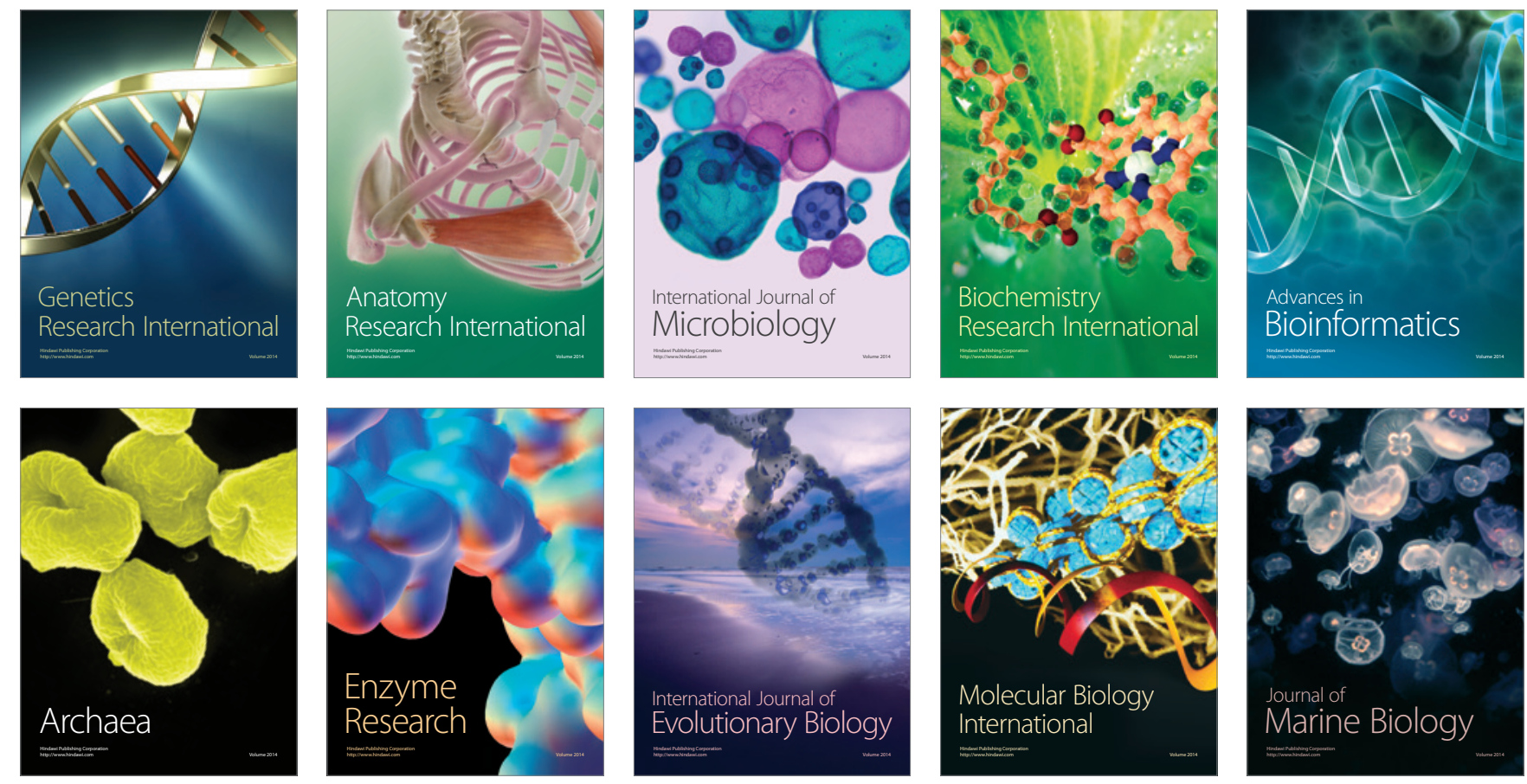